\title{
Prevalence study of compulsive buying in a sample with low individual monthly income
}

\author{
Estudo de prevalência de compra compulsiva em uma amostra com baixo \\ rendimento mensal individual
}

Priscilla Lourenço Leite, Adriana Cardoso Silva*

\begin{abstract}
Introduction: Compulsive buying can be characterized as an almost irresistible impulse to acquire various items. This is a current issue and the prevalence rate in the global population is around 5 to $8 \%$. Some surveys indicate that the problem is growing in young and low-income populations.

Objectives: To evaluate the prevalence of compulsive buying among people with low personal monthly incomes and analyze relationships with socio-demographic data.

Methods: The Compulsive Buying Scale was administered to screen for compulsive buying and the Hospital Anxiety and Depression Scale was used to assess anxiety and depression in a sample of 56 participants. Pearson coefficients were used to test for correlations.

Results: The results indicated that $44.6 \%$ presented an average family income equal to or greater than 2.76 minimum wages. It is possible that compulsive buying is not linked to the purchasing power since it was found in a low-income population.

Conclusion: Despite the small sample, the results of this study are important for understanding the problem in question.

Keywords: Epidemiology, low-income population, compulsive behavior.
\end{abstract}

\section{Introduction}

Compulsive buying is a modern disorder that has been attracting growing attention over recent years. The condition is caused by living in a consumer society

\section{Resumo}

Introdução: A compra compulsiva pode ser caracterizada como um impulso quase irresistível de obter diversos itens. Considerada um problema da atualidade, estima-se que sua taxa de prevalência seja em torno entre 5 a $8 \%$ na população mundial. Algumas pesquisas sinalizam um aumento do problema entre jovens e populações de baixa renda.

Objetivos: Avaliar a prevalência da compra compulsiva em sujeitos com baixa renda mensal individual e analisar as relações entre os dados sociodemográficos.

Método: A Compulsive Buying Scale (CBS) foi utilizada para rastrear compra compulsiva, e a Hospital Anxiety and Depression Scale (HADS), para avaliar ansiedade e depressão em uma amostra de 56 participantes. Correlações foram verificadas através do teste de Pearson.

Resultados: Os resultados indicaram que $44,6 \%$ apresentavam renda média familiar igual ou maior a 2,76 salários mínimos. É possível que a compra compulsiva não esteja vinculada ao poder aquisitivo, uma vez que ela foi encontrada em uma população com baixa renda.

Conclusão: Embora a amostra seja pequena, os resultados obtidos são importantes para compreender o problema em questão. Descritores: Epidemiologia, população baixa renda, comportamento compulsivo.

that stimulates, encourages and directs purchasing and bases its notions of wellbeing on the material and it is possibly more common than had been thought. ${ }^{1}$ However, because the subject is rarely discussed in the scientific

\footnotetext{
* Laboratório do Pânico e Respiração, Instituto de Psiquiatria, Universidade Federal do Rio de Janeiro (UFRJ), Rio de Janeiro, RJ, Brazil. Instituto Nacional de Ciência e Tecnologia - Medicina Translacional (INCT-TM).

Financial support: Coordenação de Aperfeiçoamento de Pessoal de Nível Superior (CAPES).

Submitted Mar 19 2015, accepted for publication May 25 2015. No conflicts of interest declared concerning the publication of this article. Suggested citation: Leite PL, Silva AC. Prevalence study of compulsive buying in a sample with low individual monthly income. Trends Psychiatry Psychother. 2015;37(4):209-212. http://dx.doi.org/10.1590/2237-6089-2015-0015
} 
literature, a fact reflected in the lack of studies and research investigating the subject, the characteristics of compulsive buying need to be better explored.

Originally described by Kraepelin ${ }^{2}$ as oniomania, compulsive buying is characterized by an irresistible, repetitive and dominating desire to buy items. ${ }^{3}$ This impulse is uncontrollable and patients can only find relief from stress through indulging in excessive shopping. However, the feeling of wellbeing produced by the reduction in tension is quickly replaced by a sense of guilt. ${ }^{3}$ Compulsive buying is considered an addictive behavior, seen as a social phenomenon, and it has been hypothesized that many North-American consumers succumb to purchase to fill a void in themselves. ${ }^{4}$

Although compulsive buying is not defined as a disorder in the 5th edition of the Diagnostic and Statistical Manual of Mental Disorders (DSM-5), ${ }^{5}$ the classification proposed by McElroy et al. ${ }^{6}$ has been widely accepted and is commonly used in the compulsive buying literature. ${ }^{6}$

Age of onset has been described by various authors at between 18 and 30 years old. ${ }^{6-8}$ There are studies reporting on the disorder in countries such as England, France, Germany, Brazil and the United States. ${ }^{3,9-12}$ Compulsive buying can lead to public debt (58.3\%), inability to make payments $(41.7 \%)$, legal and financial consequences $(8.3 \%)$, problems and legal penalties $(8.3 \%)$ and feelings of guilt $(45.8 \%){ }^{13}$

In a prevalence study in the American population, ${ }^{12}$ it was estimated that 2 to $8 \%$ of Americans are worried about their habits of buying compulsively. Compulsive buying seems to be limited by the level of development of the countries concerned, and its cause can be correlated to the high level of industrialization, with an exception being the wealthy elites from underdeveloped countries. ${ }^{12,14}$

The materialist stimuli of the consumer society, such as easy availability of credit and online shopping, contribute to increasing the problem, especially among young and low-income populations. Young people, who have little experience in managing their finances, feel themselves being encouraged to buy and lose control when using credit cards, which is a form of suppressing parental neglect, ${ }^{3}$ thereby incurring debts and developing a distorted relationship with consumption. Some studies indicate that compulsive buying is more prevalent in young populations. ${ }^{7}$ In Brazil, it is estimated that compulsive shopping affects people aged between 14 and 25 years. ${ }^{15}$

Another important aspect is the relationship between family income and the compulsion to buy. According to some studies, there appears to be an inverse relationship between the two, because of deficient information processing relating to acquisition of the product and low levels of consumer insight. People with low incomes may have a tendency to compulsive buying because of their "little ability to control or delay their urges to make inappropriate purchases."16 It has also been suggested that buying may produce a sensation of social ascent, by masking or replacing the buyer's real social conditions with the idealized social condition. ${ }^{12,17}$

In a prevalence study of 2,513 adults, the income distribution of participants was assessed, finding that $54.7 \%$ of compulsive buyers reported low incomes, compared to the other participants. The aim of this study is to evaluate the prevalence of compulsive buying among people with low monthly family incomes and analyze relationships with socio-demographic data. The relevance of this research lies in its status as a pioneering study in the area, which has been widely investigated in international studies.

\section{Methods}

This study enrolled 56 participants, aged between 19 and 55 years, in an attempt to include strata representative of the general population. The inclusion criterion was age of 18 to 80 years. The exclusion criteria were semiliteracy age lower than 18. A structured questionnaire was designed specifically for the survey to collect demographic data. The degree of impairment associated with compulsive buying behavior was investigated using the Compulsive Buying Scale (CBS). ${ }^{14,18}$ The CBS is a 7-item scale designed to assess compulsion in purchasing. The lower the score, the greater the likelihood of a compulsion to shop. The Hospital Anxiety and Depression Scale (HADS) comprises 14 items, 7 of which assess anxiety and 7 of which assess depression. Each item is scored 0 to 3 , giving a maximum score of 21 points for each subscale. The surveys were conducted using an online platform and because of this the procedures adopted were tailored to the specific requirements of administering instruments via the internet. Thus, when the people who were invited to participate accessed the survey site they could accept or refuse to participate in the study. Those who wished to participate were requested to complete a Statement of Informed Consent (IC). They were then asked to respond to a protocol containing the 2 instruments used for this study, accompanied by brief instructions for completing each instrument.

The chi-square test was used for description of demographic variables. Clinical correlations were identified using Pearson coefficients with a $\mathrm{p}$-value of less than 0.05 adopted as the cutoff for statistical significance. The study was approved by the research ethics committee and all procedures are in accordance with recommendations and requirements for research. 


\section{Results}

The sample comprised 56 participants, all with an average personal income of US\$212. Additionally, 48 $(85.7 \%)$ of the participants were female, $50(89.3 \%)$ were married, $42(75.0 \%)$ had not completed college, 50 $(89.3 \%)$ were full-time students at the time they were evaluated and $25(44.6 \%)$ had an average family income equal to or greater than US\$896, but less than US\$ 2,914 , equivalent to from 2.76 to 8.98 times the Brazilian minimum wage. Most of the population interviewed lived in the southeastern region of Brazil (50.0\%) (Table 1).

The results of the instrument for assessing compulsive buying indicated that $3(5.4 \%)$ of the participants had this disorder. According to Koran et al. ${ }^{12}$ there is a $5.8 \%$ prevalence of compulsive buying in the general U.S. population. Other studies indicate compulsive buying prevalence rates from 2 to $5 \%$ in economically developed countries. ${ }^{12,14}$ Scores for depression and anxiety were markedly different, with high anxiety scores in 37 $(66.1 \%)$ subjects and high depression scores in 33 $(58.9 \%)$, of the sample of 56 participants (Table 2 ).

Table 1 - Characteristics of the study sample

\begin{tabular}{|c|c|}
\hline & n (\%) \\
\hline Age, mean \pm standard deviation (range) & $\begin{array}{c}23.98 \pm 6.34 \\
(\min =19 ; \max =55)\end{array}$ \\
\hline \multicolumn{2}{|l|}{ Gender } \\
\hline Male & $8(14.3)$ \\
\hline Female & $48(85.7)$ \\
\hline \multicolumn{2}{|l|}{ Marital status } \\
\hline Single & $48(85.7)$ \\
\hline Married/stable relationship & $8(14.3)$ \\
\hline Children & $5(8.9)$ \\
\hline \multicolumn{2}{|l|}{ Education } \\
\hline Started secondary education & $0(0)$ \\
\hline $\begin{array}{l}\text { Graduated from secondary } \\
\text { education }\end{array}$ & $0(0)$ \\
\hline Started higher education & $42(75.0)$ \\
\hline Graduated from higher education & $12(21.4)$ \\
\hline Post-graduate degree & $2(3.6)$ \\
\hline \multicolumn{2}{|l|}{ Occupation } \\
\hline Student - no job & $50(89.3)$ \\
\hline Stay-at-home & $2(3.6)$ \\
\hline Unemployed & $1(1.8)$ \\
\hline $\begin{array}{l}\text { Employment: } \\
\text { unregistered/informal/self-employed }\end{array}$ & $3(5.4)$ \\
\hline \multicolumn{2}{|l|}{$\begin{array}{l}\text { Average personal income } \\
\text { (per month) }\end{array}$} \\
\hline Less than US\$217 & $56(100)$ \\
\hline \multicolumn{2}{|l|}{ Median household income (per month) } \\
\hline Equal to or greater than US\$2,914 & $22(39.3)$ \\
\hline Equal to or greater than US\$896 & $25(44.6)$ \\
\hline Equal to or greater than US\$325 & $8(14.3)$ \\
\hline Less than US\$217 & $1(1.8)$ \\
\hline \multicolumn{2}{|l|}{ Region } \\
\hline Northeast & $26(46.4)$ \\
\hline Southeast & $28(50.0)$ \\
\hline South & $1(1.8)$ \\
\hline Another country & $1(1.8)$ \\
\hline
\end{tabular}

Table 2 - Correlations between the clinical scales

\begin{tabular}{lccc}
\hline & Mean \pm SD & $\begin{array}{c}\text { Minimum; } \\
\text { maximum }\end{array}$ & $\begin{array}{c}\text { Frequency, } \\
\mathbf{n}(\%) *\end{array}$ \\
\hline CBS $(n=56)$ & $1.44 \pm 1.57$ & $-3.62 ; 3.61$ & $3(5.4)$ \\
Depression $(n=49)$ & $8 \pm 1.51$ & $5 ; 11$ & $33(58.9)$ \\
Anxiety $(n=49)$ & $12.97 \pm 2.56$ & $6 ; 17$ & $37(66.1)$ \\
\hline
\end{tabular}

$\mathrm{SD}=$ standard deviation.

* Subjects classified with CBS, depression and anxiety, according to the instruments' cutoff points.

Table 3 - Correlations between scales

\begin{tabular}{lcc}
\hline & Depression & Anxiety \\
\hline CBS & & \\
Pearson correlation & -0.004 & $0.306 *$ \\
Sig. (2-tailed) & 0.980 & 0.032 \\
N & 49 & 49 \\
Depression & & \\
Pearson correlation & & -0.068 \\
Sig. (2-tailed) & & 0.645 \\
N & & 49 \\
\hline
\end{tabular}

The CBS scale exhibited a correlation with the HADS anxiety scale $(r=0.30,0<0: 05)$. No other significant correlations between the compulsive shopping scale and the HADS depression scale and HADS anxiety scale were found (Table 3).

\section{Discussion}

Although our study was conducted with a small sample, it was still possible to detect compulsive buying disorder in three members of this population of 56 individuals with personal incomes of less than the monthly minimum wage. According to the results of the CBS scale, $5.4 \%$ of this sample have a compulsive buying disorder, which is compatible with scientific findings on the prevalence of the disorder published elsewhere.

In our study we observed a higher proportion of female respondents $(85.7 \%)$. In other studies of the epidemiology and prevalence of compulsive buying it is also common that there is higher female participation than male participation. In an American study, $65.5 \%$ of the sample recruited were women, ${ }^{12}$ and in a German study women comprised $52.1 \%$ of the sample. ${ }^{18}$ It was possible to detect that there was no statistically significant difference in the impact of compulsive buying between the sexes, although some studies have shown that women tend to be more affected by compulsive buying than men. ${ }^{19}$

With regard to educational level, none of the participants were allocated to the high school or elementary school categories. We think this is a reflection of our study population, which was mainly comprised of young adults. 
We found no significant differences in compulsive buying linked to marital status, occupation, education level, monthly income or region of the country. However, it was possible to show that younger individuals, aged between 21 and 31 years old, had a greater propensity for compulsive buying.

Another relevant aspect is the average family income. From the respondents, $44 \%$ of our sample earned equal to or greater than US\$ 896,00 , but less than US\$2914, equivalent to from 2.76 to 8.98 times the Brazilian minimum wage, indicating that the disorder is not linked to purchasing power or socio-economic level, since in order of priority, to meet all basic family needs, it is necessary to consider other priorities such as food, housing, health, transportation, education and hygiene, before leisure activities and clothing, which are the main objects of consumption of compulsive buying. ${ }^{1}$

Limitations of our study can be attributed to our sample selection strategy: online survey. Although this method has been widely used in other prevalence studies and allows us to reflect the nuances of the general population, since we can interview participants from others regions of the country with greater ease, it does not enable direct contact with the respondent, hampering the possibility of a more precise diagnosis according to the criteria proposed by McElroy et al. ${ }^{6}$ Another source of bias is the possibility of inappropriate completion by the respondents, since compulsive buying is a phenomenon that is seldom investigated and some people could incorrectly assess their own consumption profiles, because buying is behavior that is encouraged and accepted, making assessment of what should be considered excessive behavior a complex matter.

As some authors point out, ${ }^{20}$ the most appropriate technique for evaluation and diagnosis of compulsive buying would be to use structured clinical interviews. However, due to the difficulty in accessing these subjects and in attracting participants for research studies, this seems to be a limitation that requires further study.

Another limitation of our study relates to the size of our sample. As postulated previously, since this is a littleknown problem, detection and ,consequently, selection of participants is laborious.

Our results constitute important findings because they indicate the presence of compulsive buying in a population with low purchasing power. Although this study has made some advances in the direction of clarifying the dynamics of the problem of compulsive buying, there is a need to undertake further efforts to broaden understanding of the problem, particularly understanding of its impacts and consequences, in order to improve the guidelines on notions of consumption and health care.

\section{Acknowledgements}

The present work is supported by the Coordenação de Aperfeiçoamento de Pessoal de Nível Superior (CAPES).

\section{References}

1. Black DW. Compulsive buying disorder: definition, assessment, epidemiology and clinical management. CNS Drugs. 2001;15:17-27

2. Kraepelin E. Psychiatrie. 8th ed. Leipzig: Verlag von Johann Ambrosius Barth; 1915. p. 408-9.

3. Lejoyeux M, Haberman N, Solomon J, Adès J. Comparison of buying behavior in depressed patients presenting with or without compulsive buying. Compr Psychiatry. 1999;40:51-6.

4. Lee S, Mysyk A. The medicalization of compulsive buying. Soc Sci Med. 2004;58:1709-18.

5. American Psychiatric Association. Diagnostic and Statistical Manual of Mental Disorders, Fifth Edition (DSM-5). Arlington: American Psychiatric Publishing; 2013.

6. McElroy SL, Keck P Jr, Pope HG Jr, Smith JM, Strakowski S. Compulsive buying: a report of 20 cases. J Clin Psychiatry. 1994; 55:242-8

7. Schlosser S, Black DW, Repertinger S, Freet D. Compulsive buying. Demography, phenomenology, and comorbidity in 46 subjects. Gen Hosp Psychiatry. 1994;16:205-12.

8. Mitchell JE, Burgard M, Faber R, Crosby RD, de Zwaan M. Cognitive behavioral therapy for compulsive buying disorder. Behav Res Ther. 2006;44:1859-65.

9. Elliott R. Addictive consumption: function and fragmentation in postmodernity. J Consumer Policy. 1994;17:159-79.

10. Scherhorn G, Reisch LA, Raab G. Addictive buying in West Germany: an empirical study. J Consumer Policy. 1990;13:355-87.

11. Mueller A, Mitchell JE, Mertens C, Mueller U, Silbermann A, Burgard $M$, et al. Comparison of treatment seeking compulsive buyers in Germany and the United States. Behav Res Ther. 2007; 45:1629-38.

12. Koran LM, Faber RJ, Aboujaoude E, Large MD, Serpe RT. Estimated prevalence of compulsive buying behavior in the United States. Am J Psychiatry. 2006;163:1806-12.

13. Christenson GA, Faber RJ, de Zwaan M, Raymond NC, Specker SM, Ekern MD, et al. Compulsive buying: Descriptive characteristics and psychiatric comorbidity. J Clin Psychiatry. 1994;55:5-11.

14. Faber RJ, O'Guinn TC. A clinical screener for compulsive buying. J Consumer Res. 1992;19:459-69.

15. Veludo-de-Oliveira TM, Ikeda AA, Santos RC. Compra compulsiva e a influência do cartão de crédito. Rev Adm Empres. 2004;44.

16. Tavares H, Lobo DS, Fuentes D, Black DW. [Compulsive buying disorder: a review and a case vignette]. Rev Bras Psiquiatr. 2008;30:S16-23.

17. Dittmar H. Compulsive buying--a growing concern? An examination of gender, age, and endorsement of materialistic values as predictors. Br J Psychol. 2005;96:467-91.

18. Leite $\mathrm{PL}$, Range BP, Ribas RC Jr, Fernandez JL, Silva ACO. Validação e aferição de fidedignidade da versão brasileira da Compulsive Buying Scale. Rev Psiquiatr Clin. 2012;39:100-5.

19. Mueller A, Mitchell JE, Crosby RD, Gefeller O, Faber RJ, Martin $A$, et al. Estimated prevalence of compulsive buying in Germany and its association with sociodemographic characteristics and depressive symptoms. Psychiatry Res. 2010;180:137-42.

20. Neuner M, Raab G, Reisch LA. Compulsive buying in maturing consumer societies: an empirical re-inquiry. J Econ Psychol. 2005;26:509-22.

\section{Correspondence:}

Priscilla Lourenço Leite

Laboratório do Pânico e Respiração, Instituto de Psiquiatria

Universidade Federal do Rio de Janeiro, INCT-TM

Av. Venceslau Brás, 71, Botafogo

22290-140 - Rio de Janeiro, RJ - Brazil

E-mail: priscilla.ufrj@gmail.com 